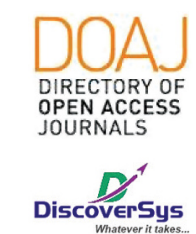

Published by DiscoverSys

\section{Perbedaan parameter analisa gas darah (AGD) pada mixing sampel sesuai dan tidak sesuai standar Clinical and Laboratory Standards Institute (CLSI)}

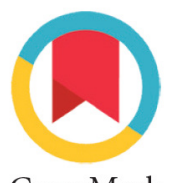

CrossMark

\author{
Diah Ayu Kusuma ${ }^{1 *}$, Banundari Rachmawati²
}

\section{ABSTRAK}

Pendahuluan: Analisis Gas Darah (AGD) merupakan bagian penting untuk mendiagnosis dan mengelola status oksigenasi dan keseimbangan asam basa pasien. Instalasi Gawat Darurat (IGD) dan perawatan intensif (ICU) menggunakan AGD sebagai bagian tak terpisahkan dari penilaian status klinis pasien. Dalam pemeriksaan AGD khususnya, pengumpulan dan penanganan spesimen darah arteri yang tidak tepat dapat menghasilkan hasil yang keliru. Pada pemeriksaan AGD salah satu kesalahan pra-analitik adalah mixing sampel yang tidak sesuai standar. Tujuan penelitian ini adalah membuktikan adanya perbedaan hasil parameter AGD antara sampel yang dilakukan mixing sesuai dengan standar Clinical and Laboratory Standards Institute (CLSI) dan yang tidak sesuai standar CLSI.

Metode: Ini merupakan studi observasional analitik potong lintang. Subjek penelitian adalah pasien usia 25-50 tahun yang dirawat di ICU RSUP Dr. Kariadi Semarang dan dilakukan pemeriksaan AGD. Analisis statistik menggunakan paired T-test dan Wilcoxon test. Dikatakan terdapat perbedaan bermakna apabila nilai $p<0.05$.

Hasil: Terdapat perbedaan bermakna pada parameter $\mathrm{p} 0^{2}(\mathrm{p}<$ $0.001)$, S02 ( $p<0.001)$, dan natrium $(p=0.038)$ antara sampel yang dilakukan mixing sesuai standar CLSI dan tidak sesuai standar CLSI. Tidak terdapat perbedaan bermakna pada parameter $\mathrm{pH}$, $\mathrm{pCO}^{2}, \mathrm{Hb}, \mathrm{Hct}, \mathrm{HCO}^{3-}$, dan $\mathrm{BE}$ antara sampel yang dilakukan mixing sesuai standar CLSI dan tidak sesuai standar CLSI.

Simpulan: Terdapat perbedaan bermakna pada parameter untuk menilai status oksigenasi antara mixing sampel sesuai dengan CLSI dan tidak sesuai CLSI. Mixing sampel yang benar diperlukan untuk mendapatkan hasil yang dapat dipertanggungjawabkan.

Kata Kunci: CLSI, Mixing sampel, Parameter AGD

Site Pasal ini: Kusuma, D.A., Rachmawati, B. 2019. Perbedaan parameter analisa gas darah (AGD) pada mixing sampel sesuai dan tidak sesuai standar Clinical and Laboratory Standards Institute (CLSI). Intisari Sains Medis 10 (1): 214-217. D0I: 10.1556/ism.v10i1.344

'Residen Bagian Patologi Klinik, Fakultas Kedokteran Universitas Diponegoro, Semarang, Indonesia ${ }^{2}$ Staf Bagian Patologi Klinik, Fakultas Kedokteran UniversitasDiponegoro, Semarang, Indonesia

\footnotetext{
* Koresponden:

Diah Ayu Kusuma;

Residen Bagian Patologi Klinik, Fakultas Kedokteran Universitas Diponegoro, Semarang, Indonesia; dr.diahayu@gmail.com
}

Diterima : 06-11-2018 Disetujui : 26-03-2019 Diterbitkan : 01-04-2019

\section{PENDAHULUAN}

Analisis Gas Darah (AGD) merupakan bagian penting untuk mendiagnosis dan mengelola status oksigenasi dan keseimbangan asam basa pasien. Tes ini merupakan tes yang rutin diminta di RS. Kegunaan alat diagnostik ini tergantung pada kemampuan menafsirkan hasil dengan benar. Gangguan keseimbangan asam-basa dapat menciptakan komplikasi pada banyak penyakit dan terkadang kelainan bisa begitu parah sehingga menjadi faktor risiko yang dapat mengancam jiwa. ${ }^{1,2}$

Menurut dokumen yang dikeluarkan oleh Croatian Chamber of Medical Biochemist (CCMB), AGD dikategorikan sebagai analisis prioritas pertama yang harus dilaporkan dalam 30 menit. $^{3}$ The American Association for Respiratory Care telah mengadopsi pedoman praktek klinik yang menganjurkan untuk pengambilan sampel, penanganan, analisis sampel darah arteri dan pelaporan segera dalam 30 menit. $^{4}$

Instalasi perawatan gawat darurat (IGD) dan perawatan intensif menggunakan AGD sebagai bagian tak terpisahkan dari penilaian status klinis pasien. ${ }^{3}$ Lingkungan dengan tingkat kesibukan dan stress yang tinggi dapat meningkatkan probabilitas kesalahan yang dapat mengakibatkan hasil yang merugikan pasien. ${ }^{3}$ Langkah-langkah pra-analitik dalam pengujian, dari memilih tes yang benar untuk memastikan spesimen dimasukkan ke dalam instrumen dengan benar, harus dikoordinasikan dengan sempurna untuk memastikan bahwa pasien menerima terapi dan waktu yang tepat. ${ }^{2}$

Evaluasi AGD penting dalam mengevaluasi kondisi pasien yang kritis. Hasil AGD dapat menjadi bias karena faktor pra-analitik, salah satunya adalah mixing sampel yang tidak sesuai standar, selain selang waktu sebelum analisis, temperatur selama penyimpanan dan jenis siring. ${ }^{6,7}$ Parameter pemeriksaan AGD terdiri dari 2 kelompok besar, yaitu parameter status asam basa $\left(\mathrm{pH}, \mathrm{HCO}^{3}-\right.$, 
dan $\mathrm{BE})$ dan parameter status oksigenasi $\left(\mathrm{PCO}^{2}\right.$, $\mathrm{PO}^{2}$, dan $\left.\mathrm{SaO}^{2}\right){ }^{8,9}$

International Federation Of Clinical Chemistry (IFCC) pada tahun 1995, melalui Komite tentang $\mathrm{pH}$, Gas Darah dan Elektrolit, telah mengembangkan rekomendasi khusus untuk meminimalkan efek yang tidak diinginkan dari variabel pra-analitik..$^{10}$ Panduan yang digunakan secara internasional adalah menggunakan Clinical and Laboratory Standards Institute (CLSI) 2001 yang merujuk pada rekomendasi IFCC. Dalam pemeriksaan AGD khususnya, pengumpulan dan penanganan spesimen darah arteri yang tidak tepat dapat menghasilkan hasil yang salah. Penyebab hasil pemeriksaan yang tidak akurat antara lain jumlah heparin yang tidak tepat dalam jarum suntik dan pencampuran yang tidak tepat setelah darah diambil. ${ }^{10-12}$

RSUP Dr. Kariadi merupakan rumah sakit rujukan tipe A di Jawa Tengah yang menangani banyak pasien. Hal ini menimbulkan tingkat kesibukan dan stress yang cukup tinggi. Pemeriksaan di laboratorium dituntut cepat dalam memenuhi turn around time suatu pemeriksaan. Hal ini berpeluang untuk menimbulkan kesalahan pra-analitik. Pemeriksaan AGD dengan waktu pelaporan yang cukup singkat, mengharuskan analis mengerjakannya dengan cepat. Dalam pemeriksaan AGD, pencampuran sampel praanalitik dilakukan tidak sesuai standard CLSI yang merujuk pada IFCC.

Mixing sampel sebelum analisis diperlukan pada sampel AGD terutama dalam penentuan konsentrasi oksigen, konsentrasi hemoglobin dan hematokrit menurut IFCC. ${ }^{10}$ Mixing juga mencegah potensi efek konsentrasi sentrifugal, yang dapat

Tabel 1. Perbedaan parameter AGD

\begin{tabular}{lccl}
\hline Parameter AGD & $\begin{array}{c}\text { Mixing tidak sesuai } \\
\text { standar CLSI }\end{array}$ & $\begin{array}{c}\text { Mixing sesuai standar } \\
\text { CLSI }\end{array}$ & p \\
\hline $\mathrm{pH}$ & $7.44(7.01-7.54)$ & $7.43(7.09-7.55)$ & $0.583^{\ddagger}$ \\
$\mathrm{pCO}^{2}$ & $36.2(18.4-118.9)$ & $38.4(18-94.4)$ & $0.436^{\ddagger}$ \\
$\mathrm{pO}^{2}$ & $138.82 \pm 52.09$ & $162.04 \pm 39.45$ & $<0.001^{\ddagger \star}$ \\
$\mathrm{pH}(\mathrm{T})$ & $7.44(7.02-7.54)$ & $7.42(7.10-7.55)$ & $0.632^{\ddagger}$ \\
$\mathrm{pCO}^{2}(\mathrm{~T})$ & $36(19.3-117.4)$ & $37.1(18.6-93.2)$ & $0.432^{\ddagger}$ \\
$\mathrm{pO}^{2}(\mathrm{~T})$ & $139.80 \pm 50.44$ & $162.99 \pm 38.12$ & $<0.001^{\ddagger *}$ \\
$\mathrm{SO}^{2} \%$ & $97.5(64-99.2)$ & $98.3(72.1-99.6)$ & $<0.001^{\ddagger \star}$ \\
$\mathrm{Hct}^{*}$ & $26.43 \pm 6.70$ & $27.89 \pm 5.84$ & $0.119^{\S}$ \\
$\mathrm{Hb}^{\S}$ & $8.75 \pm 2.22$ & $9.28 \pm 1.95$ & $0.093^{\S}$ \\
$\mathrm{Na}^{+}$ & $145.85 \pm 6.77$ & $146.79 \pm 7.06$ & $0.038^{\S \star}$ \\
$\mathrm{HCO}^{3}-$ & $22.72 \pm 6.47$ & $23.06 \pm 7.21$ & $0.230^{\S}$ \\
$\mathrm{BE}$ & $-0.9(-18.20-11.30)$ & $0.5(-19-15.70)$ & $0.89^{\ddagger}$ \\
\hline
\end{tabular}

${ }^{*}$ : Bermakna; ${ }^{\ddagger}$ : Wilcoxon; ${ }^{\S}$ : Paired $\mathrm{t}$ menyebabkan kesalahan pada sampel whole blood. Distribusi yang seragam dari sel darah merah dan plasma sebelum spesimen dianalisis merupakan persyaratan mutlak untuk hasil yang dapat diandalkan. Pencampuran sampel dan antikoagulan heparin yang tidak sempurna dapat berefek pada perubahan $\mathrm{pH}, \mathrm{pCO}^{2}$ atau $\mathrm{pO}^{2} .^{13}$

Perbedaan cara pencampuran dan pendapat mengenai seberapa pentingnya pencampuran (mixing) untuk memperoleh homogenitas sampel yang digunakan dalam preparasi sampel AGD mendorong peneliti melakukan penelitian untuk mengetahui apakah cara mixing yang tidak sesuai standar dapat mempengaruhi hasil AGD.

Tujuan dari penelitian ini adalah membuktikan adanya perbedaan hasil parameter AGD antara sampel yang di-mixing sesuai dengan standar CLSI dan yang tidak sesuai standar CLSI.

\section{METODE}

Penelitian ini merupakan penelitian observasional analitik potong lintang (cross sectional) yang dilakukan pada bulan September 2018. Subjek penelitian adalah pasien usia 25-50 tahun yang dirawat di ICU RSUP Dr. Kariadi Semarang dan dilakukan pemeriksaan AGD. Sampel pasien dikirim ke Laboratorium RSUP Dr. Kariadi dan dilakukan mixing sampel seperti yang biasanya dilakukan (tidak sesuai standar CLSI) yaitu mixing kurang dari 1 menit. Sampel kemudian dianalisis dengan menggunakan alat Phox untuk menilai parameter AGD. Kemudian, sampel didiamkan selama 5 menit, setelah itu dilakukan mixing sesuai referensi CLSI. Dilakukan inversi $10 \mathrm{kali}$, menggulung di telapak tangan selama 10 detik, dan prosedur ini dilakukan selama 2 menit. Sampel kemudian diperiksa lagi dengan alat Phox.

Data diolah menggunakan program IBM SPSS Statistic versi 25. Dilakukan uji normalitas data dengan Saphiro-wilk. Analisis statistik menggunakan uji beda paired T-test dan Wilcoxon test. Dikatakan terdapat perbedaan bermakna secara statistik apabila nilai $\mathrm{p}<0.05$.

\section{HASIL}

Besar sampel yang didapat adalah sebanyak 37 sampel. Terdapat dua parameter AGD yaitu parameter yang didapat dari hasil pengukuran langsung analyzer (measured) dan parameter yang didapat dari hasil perhitungan alat (calculated).

Pada Tabel 1, dapat dilihat bahwa terdapat perbedaan bermakna antara sampel yang dilakukan mixing sesuai standar CLSI dan tidak sesuai standar CLSI pada tiga parameter AGD yaitu $\mathrm{pO}^{2}$ $(\mathrm{p}<0.001), \mathrm{SO}^{2} \%(\mathrm{p}<0.001)$ dan natrium $(\mathrm{p}=$ 
0.038). Sedangkan parameter $\mathrm{pH}, \mathrm{pCO}^{2}, \mathrm{Hb}, \mathrm{Hct}$, $\mathrm{HCO}^{3}$ dan $\mathrm{BE}$ tidak menunjukkan perbedaan yang bermakna.

\section{DISKUSI}

Parameter pemeriksaan AGD terdiri dari 2 kelompok besar, yaitu parameter status asam basa $\left(\mathrm{pH}, \mathrm{HCO}^{3}-\right.$, dan $\left.\mathrm{BE}\right)$ dan parameter status oksigenasi $\left(\mathrm{PCO}^{2}, \mathrm{PO}^{2}\right.$,dan $\left.\mathrm{SaO}^{2}\right)$. Pada penelitian ini, terdapat perbedaan bermakna pada parameter $\mathrm{pO}^{2}, \mathrm{SO}^{2}$ dan natrium antara metode mixing sesuai CLSI dan tidak sesuai CLSI. Walaupun hal ini tidak mempengaruhi parameter status asam basa, tetapi mempengaruhi penilaian status oksigenasi dari pasien.

Penelitian ini sesuai dengan penelitian yang dilakukan oleh Grenache et $\mathrm{al}^{15}$ pada tahun 2006. Mixing sampel yang berbeda menyebabkan hasil AGD berbeda secara bermakna. Grenache et $\mathrm{al}^{15}$ memeriksa 388 sampel whole blood untuk analisis gas darah dengan membandingkan mixing sampel secara manual dan automatic. Pada penelitian tersebutdidapatkankesimpulan bahwa mixingsecara manual menghasilkan variasi dalam pengukuran $\mathrm{Hb}$ (hemoglobin). ${ }^{15}$ Penelitian ini juga didukung dengan penelitian yang dilakukan oleh Giuseppe et $\mathrm{al}^{16}$ tahun 2007, dimana penelitian tersebut mengevaluasi 60 sampel EDTA dari 20 orang. Pada penelitian tersebut didapatkan penurunan nilai yang bermakna untuk hemoglobin, hematokrit, RBC (red blood cell) dan jumlah trombosit pada sampel yang tidak dilakukan inversi, inversi sebanyak 6 kali, dan inversi sebanyak 12 kali. $^{16}$ Hasil penelitian ini bertentangan dengan penelitian Parenmark et $\mathrm{al}^{17}$ tahun 2011 yang menyatakan tidak terdapat perbedaan yang bermakna pada 50 sampel darah vena yang dilakukan instant mixing, tidak dilakukan mixing, dan sampel yang didiamkan 5 menit kemudian dilakukan mixing. ${ }^{17}$

Mencampur sampel darah utuh (whole blood) penting untuk pencampuran antikoagulasi heparin yang tepat dan untuk memastikan hasil yang akurat. Untuk jarum suntik, segera setelah mengeluarkan udara (bubble) yang terperangkap. Teknik anaerob untuk pengambilan spesimen AGD yaitu dilakukan tanpa adanya kontak darah dengan udara atmosfer. ${ }^{10,13,18} \mathrm{PCO}^{2}$ atmosfer kira-kira $0.25 \mathrm{~mm} \mathrm{Hg}$, lebih rendah daripada $\mathrm{PCO}^{2}$ darah $(\approx 40 \mathrm{~mm} \mathrm{Hg}){ }^{18} \mathrm{CO}^{2}$ dan $\mathrm{PCO}^{2}$ darah yang telah berkenaan dengan udara atmosfer, nilainya akan menurun, sedangkan $\mathrm{pH}$ darah akan naik. Darah dapat berkenaan dengan udara yang berasal dari jarum dan "dead space" siring. ${ }^{18}$

Sensor potensiometri untuk $\mathrm{pH}$ dan sodium didasarkan pada perbedaan komposisi membran kaca yang diperoleh melalui campuran logam- alkali oksida. ${ }^{19}$ Sensor potensiometri untuk kalium, kalsium, klorida, lithium, dan magnesium didasarkan pada membran matriks polimer yang mengandung bahan elektroaktif yang membuat membran selektif untuk penentuan jenis ion masing-masing dalam darah. Sensor potensiometri diperoleh dengan menggabungkan membranmembran tersebut ke dalam struktur yang disebut Ion Selective Electrodes (ISE). ${ }^{19}$ Hal ini juga merupakan faktor perlunya sampel yang homogen. Elektrolit sendiri digunakan untuk menilai anion gap $\left[\left(\mathrm{Na}^{+}+\mathrm{K}^{+}\right)-\left(\mathrm{Cl}^{-}+\mathrm{HCO}^{3-}\right)\right]$ yang dapat membantu dalam penegakan diagnosis asidosis metabolik. Pada penelitian ini didapatkan hasil yang berbeda bermakna pada hasil natrium $(\mathrm{p}<0.038)$. Tetapi terdapat keterbatasan pada penelitian ini, karena alat Phox hanya dapat memeriksa natrium, sedangkan kalium dan klorida tidak diperiksa.

Pada instrumen AGD yang ada saat ini, penentuan tekanan parsial $\mathrm{CO}^{2}\left(\mathrm{PCO}^{2}\right)$ dilakukan dengan sensor potensiometri, yang disebut sensor Stowe-Severinghaus. Hanya $5 \%$ dari $\mathrm{CO}^{2}$ yang masuk ke darah dan menetap dalam plasma, sisanya masuk ke dalam eritrosit. Sejumlah kecil $\mathrm{CO}^{2}$ plasma membentuk asam karbonat dan sisanya tetap sebagai $\mathrm{CO}^{2}$ terlarut/dissolved $\left(\mathrm{dCO}^{2}\right)$, memberikan tekanan (hukum Henry) yang diukur sebagai $\mathrm{PCO}^{2}$. Dissolved $\mathrm{CO}^{2}$ berdifusi melalui membran permeabel gas dan merubah $\mathrm{pH}$ dari lapisan tipis elektrolit berbasis bikarbonat. ${ }^{19}$

Variasi $\mathrm{pH}$ larutan bikarbonat yang diukur dengan sensor $\mathrm{pH}$ berbanding lurus dengan logaritma tekanan parsial $\mathrm{CO}^{2}$ terlarut dalam sampel. ${ }^{19}$ Sehingga dapat dilihat pada hasil sebelumnya, $\mathrm{CO}^{2}$ dan $\mathrm{pH}$ juga tidak memiliki perbedaan yang bermakna.

$\mathrm{HCO}^{3}$ dan $\mathrm{BE}$ memiliki unsur $\mathrm{pH}$ dan $\mathrm{pCO}^{2}$ dua dalam perhitungannya, sehingga memiliki hasil yang juga tidak bermakna. $\mathrm{PO}^{2}$ diukur secara amperometri. Sebagian besar kandungan total oksigen dalam darah terikat pada hemoglobin. ${ }^{19}$ Sisanya larut dalam plasma dan $\mathrm{PO}^{2}$ (kuantitas yang diukur) secara langsung berkaitan dengan konsentrasi $\mathrm{O}^{2}$ terlarut/dissolved dalam plasma. ${ }^{19}$ Jika sel darah merah yang mengikat hemoglobin tidak tercampur dengan sempurna atau tidak homogen, maka akan mempengaruhi hasil $\mathrm{O}^{2}$. Pada penelitian ini terdapat perbedaan bermakna pada parameter $\mathrm{O}^{2}$ tetapi tidak pada hemoglobin. Hal ini kemungkinan terjadi karena adanya abberant hemoglobin yang tidak terperiksa pada beberapa pasien ICU. Keadaan ini dapat menyebabkan bias karena pada penelitian ini anemia dan hemoglobinopati tidak dieksklusi.

Penelitian ini menunjukkan bahwa hasil AGD (status oksigenasi) pada mixing sampel yang 
tidak sesuai standar CLSI mempunyai nilai yang lebih rendah dibandingkan hasil AGD dari sampel yang sesuai dengan standar CLSI. Hal ini akan berpengaruh pada penatalaksanaan pasien.

\section{SIMPULAN}

Terdapat perbedaan bermakna pada parameter untuk menilai status oksigenasi antara mixing sampel sesuai dengan CLSI dan tidak sesuai CLSI. Mixing sampel pra-analitik sesuai standar diperlukan dalam menentukan status oksigenasi pasien, yang nantinya akan berpengaruh terhadap tindakan dan terapi yang diberikan oleh klinisi.

\section{REFERENSI:}

1. Kellum JA. Making Strong Ion Difference the "Euro" for Bedside Acid-Base Analysis. Yearbook of Intensive Care and Emergency Medicine. Spr Ber Heid Publ. 2005;5:67585 .

2. Baird G. Preanalytical considerations in blood gas analysis. Biochem Med (Zagreb). 2013;23(1):19-27.

3. Dukić L, Kopčinović LM, Dorotić A, Baršić I. Blood gas testing and related measurements: National recommendations on behalf of the Croatian Society of Medical Biochemistry and Laboratory Medicine. Biochem Med (Zagreb). 2016;26(3):318-336. DOI: 10.11613/ BM.2016.036.

4. American Association for Respiratory Care. AARC Clinical Practice Guideline: Blood Gas Analysis and Hemoximetry: 2001 Revision and Update. Respir Care. 2001;46(5):498505.

5. Mohammadhoseini E, Safavi E, Seifi S, Seifirad S, Firoozbakhsh S, Peiman S. Effect of Sample Storage Temperature and Time Delay on Blood Gases, Bicarbonate and $\mathrm{pH}$ in Human Arterial Blood Samples. Iran Red Crescent Med J. 2015;17(3):e13577. DOI: 10.5812ircmj.13577.

6. Plebani M. The detection and prevention of errors in laboratory medicine. Ann Clin Biochem. 2010;47(Pt 2):10110. DOI: $10.1258 /$ acb.2009.009222.

7. Hawkins R. Managing the Pre- and Post-analytical Phases of the Total Testing Process. Ann Lab Med. 2012;32(1):5-16. DOI: $10.3343 / \mathrm{alm} .2012 .32 .1 .5$.

8. Timan IS, Wulandari D, eds. Pendidikan berkesinambungan Patologi Klinik 2013: simposium analisis gas darah dan elektrolit. Jakarta: Departemen Patologi Klinik Fakultas Kedokteran Universitas Indonesia;2013.

9. The blood gas handbook. Denmark: Radiometer Medical ApS; 2011.

10. Burnett RW, Covington AK, Fogh-Andersen N, Külpmann
WR, Maas AH, Müller-Plathe O. International Federation of Clinical Chemistry (IFCC). Scientific Division. Committee on $\mathrm{pH}$, Blood Gases and Electrolytes. Approved IFCC recommendations on whole blood sampling, transport and storage for simultaneous determination of $\mathrm{pH}$, blood gases and electrolytes. Eur J Clin Chem Clin Biochem. 1995;33(4):247-53.

11. WHO Guidelines on Drawing Blood: Best Practices in Phlebotomy. Geneva: World Health Organization; 2010. ISBN-13: 978-92-4-159922-1. Available at: http://www. ncbi.nlm.nih.gov/books/NBK138650/. Accessed: October 26th 2014.

12. D'Orazio P, Ehrmeyer SS, Jacobs E, Toffaletti JG, Wandrup $\mathrm{JH}$. Blood Gas and pH Analysis and Related Measurements; Approved Guideline - Second Edition. CLSI document C46-A2. 2009;29(8).

13. Narayanan S. Preanalytical issues related to blood sample mixing. Department of Pathology and Laboratory Medicine Weill Medical College of Cornell University New York. Available at: https://acutecaretesting.org/en/articles/ preanalytical-issues-related-to-blood-sample-mixing

14. Hennessey IA, Japp AG. Arterial Blood Gases Made Easy. $1^{\text {st }}$ ed. Sydney; Churchill Livingstone Elsevier;2007.

15. Grenache DG, Parker C. Integrated and automatic mixing of whole blood: an evaluation of a novel blood gas analyzer. Clin Chim Acta. 2007;375(1-2):153-7. DOI: 10.1016/j. cca.2006.07.002.

16. Lippi G, Salvagno GL, Montagnana M, Banfi G, Guidi GC. Evaluation of Different Mixing Procedures for K2 EDTA Primary Samples on Hematological Testing. Laboratory Medicine. 2007;38(12):723-5. DOI: 10.1309/95R8A56BDN10AUUH.

17. Parenmark A, Landberg E. To mix or not to mix venous blood samples collected in vacuum tubes?. Clin Chem Lab Med. 2011;49(12):2061-3. DOI: 10.1515/CCLM.2011.705.

18. Scott MG, LeGrys VA, Hood JL. Electrolytes and blood gases. In: Burtis CA, Ashwood ER, Burns DE, eds. Tietz textbook of clinical chemistry and molecular diagnostics. Missouri: Elsevier Saunders; 2012:807-36.

19. Cristalli C, Manzoni A. Basics of blood gas instrumentation. In: Bronzino JD, ed. The biomedical engineering handbook. Boca Raton: CRC Press LLC; 2000.

20. $\mathrm{PCO} 2$ and calculated values for $\mathrm{HCO} 3$, base excess and anion gap. USA: Abbott Point of Care Inc.; 2013 (cited 2015 Mar 21). Available from: URL: http://www. abbottpointofcare.com/Customer-Info Center/ViewFile. aspx?id=802 4C5D4DD49415E948A6A09434CB6DD.

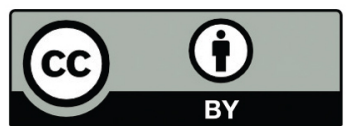

This work is licensed under a Creative Commons Attribution 